\title{
Adoption Model of Social Customer Relationship Management in the Palestinian Banking Sector
}

\author{
Maha Ramadan ${ }^{1,2} \&$ Derar Eleyan ${ }^{3,4}$ \\ ${ }^{1}$ Indiana University of Pennsylvania, Indiana, Pennsylvania, USA \\ ${ }^{2}$ Arab American University, Jenin, Palestine \\ ${ }^{3}$ Applied Computing Department, Palestine Technical University Kadoorie, Tulkarem P.O. Box 7, Palestine \\ ${ }^{4}$ Faculty of Engineering and Information Technology, Arab American University, Jenin-Palestine, P.O.Box 240 \\ Jenin, 13, Zababdeh \\ Correspondence: Maha Ramadan, Indiana University of Pennsylvania, Indiana, Pennsylvania, USA \& Arab \\ American University, Jenin, Palestine.
}

Received: December 2, 2020

Accepted: June 3, 2021

Online Published: June 7, 2021

doi:10.5539/mas.v15n4p23

URL: https://doi.org/10.5539/mas.v15n4p23

\begin{abstract}
Social CRM is a new technology that integrates social networking activities within traditional CRM itself. Social media might be the most effective strategy in the context of CRM technology concerning the availability of efforts and time by owners. Therefore, it's important for financial institutions to take advantage of it upon this opportunity by considering social CRM as part of development and enhancing relationship with their customers. Nevertheless, little empirical studies have focused on adoption of social CRM in banking sector. This research paper aims to investigate the factors that impact banks' intention to adopt social CRM, based on combining the Technology-Organization-Environment (TOE) with Technology Acceptance Model (TAM) as the theoretical framework. TOE variables such as top management support and relative advantages found to have a direct impact on the two TAM mediating variables (perceived usefulness and perceived ease of use), and an indirect impact on social CRM adoption. Further, results suggested that consumer pressure and competitive pressure have a direct impact on social CRM adoption. The researcher tested the hypothesis using structural equation modeling (SEM). The findings from a survey of 220 employees in banks in Palestine showed that all eight hypotheses were supported as both consumer pressure and competitive pressure in the environmental context have a significant direct impact on social CRM adoption intention, followed by top management support in organizational and technological contexts; relative advantages have the most significant impact on perceived ease of use and perceived usefulness which in turn, have a direct and significant impact on social CRM adoption intention. The contribution of the study, limitations, future studies and conclusion are presented.
\end{abstract}

Keywords: Banks, Social CRM, Technology-Organization-Environment framework, Technology Acceptance Model, Structural Equation Modeling

\section{Introduction}

Social media has become a new phenomenon that is challenging the traditional relationship between organizations and their customers (Abed, 2020). Moreover, it's a technology that allows customers to produce content, and interact in the social media environment with others and with businesses (Ahani, Rahim, and Nilashi, 2017; Cheng, \& Shiu, 2019). Customer relationship management (CRM) is considered as a set of marketing principles, strategies and processes introduced in order to retain current customers and attract new ones through managing relationship (Choudhury \& Harrigan, 2014). Institutions utilize CRM system in order to gain some advantages such as increasing customer satisfaction by enhancing their personalized services and build a competitive advantage (Garrido, Lockett and Morales, 2014). Since customer loyalty and customer retention are key benefits of a CRM system to an organization, working to retain existing customers by managing relationships with them can reduce costs of customer service and increase the organization's revenues, as improving customer data sharing can contribute to more cross sales and up-sales opportunities and more effective targeting and customer segmentation (Swift, 2001). On the other hand, traditional CRM strategies such as collecting and tracking data could face some difficulties institutes in gathering and analyzing information such 
as taking more money, time and effort especially when having other issues that impact the success of the marketing strategy, for example, fewer resources, knowledge and employees. (Doole, Grimes, and Demack, 2006). Nevertheless, incorporating social media with CRM gathers feedback in real time and allows people to engage with each other via social media (Harrigan \& Miles, 2014). Moreover, social media could be the most proper customer relationship management technology for institutions, mostly because social media seems to be suitable for their intuitive way of management, and_compared with traditional CRM technologies, institutions could afford social CRM technology due to their lower cost of adoption (Harrigan \& Miles, 2014). Consequently, the integration of customer relationship management with social media created the new concept of social customer relationship management (Social CRM); that has been evoked in 2007 by the grow of social media for business (Greenberg, 2010; Jacwicz \& Cho, 2015). Social CRM allows companies to influence their customer's trusted peer network to create a positive and well-known brand perception, where personal knowledge and peer interaction can help to create trust in network interactions by accessing more confident information on services and products (Sarner, Thompson, Dunne, and Davies, 2010).

In this new era of social media, banks could not only depend on one-way advertising strategy without interaction and listening to their customers. Banks began to recognize that they should increase their attention to the voices of their customers and make more modifications to their strategies, since social media has forced them to change the way they deal with customers (Mostafapour \& Heydariyeh, 2018). Although technologies such as social CRM could offer better alternatives and solutions to communicate with customers, it can be difficult to be integrated effectively into the bank's existing system (Yoon \& Sin, 2016). Therefore, there is a need to identify factors that impact their intention to involve in the programs of social CRM, which could be a key of success for social CRM implementation as this study indicates.

Some researchers depend on TAM model such as Askool and Nakata (2011), to explore the important factors affecting social CRM acceptance, and others relied on TOE theory (Ahani et al., 2017; Marolt Zimmermann, Žnidaršič, and Pucihar, 2020; Hasani, 2017). But there's a gap in studying TOE variables as an external variables of TAM variables in banking sector. Therefore, the aim of this quantitative cross-sectional study is to investigate the factors that impact social CRM adoption. Moreover, the main contribution relies on the integration between TOE theory and TAM model to generate a more comprehensive framework that identifies the factors impact social CRM adoption in banks.

\section{Literature Review}

\subsection{Social Customer Relationship Management (Social CRM)}

Social CRM is a fairly new concept which appeared with the rise of popularity of social media use in the business (Greenberg, 2010; Jacewicz \& Cho, 2015). It is defined as a philosophy and a business strategy where technology platforms, social media, social networks and business rules are all utilized to create an open, transparent and collaborative business environment with the customers, in order to respond to their views and needs and ultimately achieve mutual benefits (Greenberg, 2010). It shows the growth of complete customer ownership of the relationship, as companies working to find their customer in their preferred social media channel, trying to get some valuable information about customer's needs (Farnsworth, 2015). Thus, social networking does not replace the traditional activities; it augments them and makes them better, as the major difference between social and traditional CRM is that SCRM integrates the social networking activities within the CRM itself (Jameison, 2014). In other words, it builds on the CRM that utilizes social media tools which consequently benefit all customers and raise their trust (Askool \& Nakata, 2010; Faase, Helms, and Spruit, 2011; Roebuck, 2011), the scope is wide as most websites allow interaction and are considered social websites due to the nature of the Internet through Web 2.0 (Chau and Xu, 2012).

Social CRM allows small business to reach and interact with their customers through different means by incorporating social media (Harrigan \& Miles, 2014); Furthermore, companies have recognized the need to integrate social networking sites (SNSs) into their existing CRM initiatives and strategies to build long-term meaningful relationships with social customers (Yoon \& Jeanetta, 2014).

According to Yoon \& Sim (2016) social networking and Web 2.0 technology are employed in Social CRM including social media and social networks such as Facebook, LinkedIn, Twitter, Google+, YouTube, Flickr, Tumblr, Instagram to name a few. Also, all the Google network and peer-to-peer websites including blogs, wikis, podcasts, photo and video sharing are considered social CRM tools (Chau and Xu, 2012; Chen and chiu, 2012). The dynamism of those tools and the sustainable ways in which they can be collected, analyzed and integrated with CRM, sheds the light on the true long-term benefits of social CRM (Guha, Harrigan, and Soutar, 2018); Several methods can be used to implement social CRM, such as collecting, analyzing and interpreting customers 
perceptions, create personalize customer experiences, monitoring the social CRM performance, creating a supportive and nurturing relationships with the customers, all of those methods should be employed in a way that engages customers as partners in creating their own experiences (Sigala, 2018).

\subsection{Benefits of SCRM}

Some of the potential benefits of Social CRM might be similar to those of traditional CRM, such as improving customer loyalty, retention and generating better revenues (Bridge, 2017); nevertheless, there are some differences between them as well. Although Social CRM incorporates the features of social media within the CRM implementation, its benefits do not merely come from CRM system itself, but rather from the potential and capabilities of social application (Lehmkuhl \& Jung, 2013; Yawised, Ellis, and Wong, 2017). Thus, such applications allow companies leading to an ongoing interactive exchange that helps companies to obtain new knowledge about those customers, and to enhance customer loyalty (Lehmkuhl \& Jung, 2013).

Real time engagement and interaction on a personal level through the use of social media for CRM allows institutions to build a strong, open and trustful relationship with their customers. They also could customize the relationships if they use the data gathered from CRM activities effectively. The digital data gives valuable information about customers preferences, patterns, and competitive activity (Harrigan \& Miles, 2014).

More advantages of social networking under Web 2.0 in making communication with customers in banks, such as accessing to more customer's information, new advertising opportunities, the possibility of outsourcing applications and features on social networks, and more users' participation in the creation of database due to its user-friendly environment (Ahmadalinejad and Nabavi, 2016).

Results of a research conducted by Elfarmawi (2019) in the United States, showed that the use of CRM is linked with higher customer satisfaction, and strongly suggested that it's proper use could not only improve the relationships with current customers, it also can attract potential customers and win back former ones. Besides organizational benefits, customers can also benefit from Social CRM in other ways, it gives them the ability to control the amount of information they get instead of being overloaded with information given by the company; they feel they are more involved in their own decision as they interact and share experiences with peers or specific communities and with business leaders and experts, which helps fulfill their emotional needs. They would also receive relevant offers more often by increasing their responsiveness, ongoing dialogues with the organizations and receiving relevant offers more (Sarner et al., 2010; Harrigan, Soutar, Choudhury, and Lowe, 2015). Social marketing stimulate innovation as managers continuously seek ways to gain competitive advantage which adds a great value to their marketing strategies (Katsioloudes, Grant, and McKechnie, 2007; Trainor, Andzulis, Rapp, and Agnihotri, 2014); Firms' innovation performance improves when their customers are involved in using social media and at the same time, they acquire a high level of capability in processing customers' information and involvement (Wang and Kim, 2017). Other researcher found that out of all customers outcomes, customers' loyalty and satisfaction are the most commonly examined (Marlot and Zimmermann, 2015; While Kupper, 2014; Charoensukmongkol \& Sasatanun, 2017).

Due to the fact that a number of customers of financial institutions were lost due to long time to respond by customer service, social CRM is a good and cheap alternative to rebuild the powerful interaction of customers. As using social CRM technology in banking industry creates a new perspective on providing services to specific customers by collecting information from social CRM and promotes P2P system by creating interest in clients due to sharing their experiences and interests (Ujwala, 2015). For example, using social media in banks have a positive impact that can eventually lead to increased contribution margin per customer (Hohler, 2016).

The social CRM can provide a competitive advantage for financial institutions if they are able to use social media to their advantage (Garrido-Moreno et al., 2014), there is a need to ensure that SM is used effectively, through strategic approach with clear objectives and defined key performance indicators as the simple introduction of SM is not enough (McCann \& Barlow, 2015; Hoffman \& Fodor, 2010).

\subsection{Challenges of Implementing SCRM}

Technologies such as social CRM could offer better alternatives to communicate with customers; However, it can be difficult to be integrated effectively into the banks existing system, especially if there was a lack of technological knowledge and skilled employee (Yoon \& Sin, 2016) in addition to the lack of confidence in its return (Yawise et al., 2017), hence mangers need to appreciate the importance to employ specialized IT workforce with the skills needed to support business growth in order to adopt innovation (Gangwar \& Ramaswamy, 2015). Banks with strong and well-prepared IT infrastructure along with skilled and knowledgeable staff are more likely to heavily use CRM, (Alshawi et al., 2011; Marolt, 2018). 
Barriers in using SCRM strategy in banking industry include restrictive laws in some developing countries, uncertainty and feeling of insecurity as well as data extraction problems (Mostafapour \& Heydariyeh, 2015). Organizations' innovation capability could be a critical aspect in overcoming various challenges that could hinder their development, such as institutional barriers, low demand, lack of fund and qualified employees (Doern, 2009). Lack of resources, data management, privacy and control are key issue in implementing social CRM, companies need to invest sufficient resources in order to develop the integrated customer data base, which is considered the foundation of social CRM, otherwise they will suffer a financial loss (Tainor et al., 2014). Another challenge that could face the implementation of social CRM is its complexity, this is determined by the perceptions of the level of its difficulty, and the level of support the company provides its employees to learn and use the new technology, the easier the company perceives the use of new technology the less complex its use is perceived by employees (Ahani et al., 2017).

Similarly, Garrido-Moreno et al. (2014) discussed the impact of the organization culture on using suitable resources of social RCM and delivering the required training for successful implementation. Open communication environment if not integrated well in the company culture could have negative consequences such as security and confidentiality risks in addition to negative reactions by the staff which could obstruct the social CRM implementation (Cappuccio et al., 2012). Moreover, it is essential to reinvent the traditional CRM approaches when using social media, companies should reduce the gap between what they offer and what the customers seek when using social media in order to be able to meet their needs and requirements, companies could confuse their own desires with the consumers motivation for engaging (Heller \& Parasnis, 2011).

The difficulty in Adoption of SCRM should not be understated; however, if knowledge and information about customers and market is utilized effectively it will lead to successful interactions which enables the firm to integrate social networking and the customer-oriented service systems.

\subsection{Theoretical Background}

Researchers link the conceptual models of their studies with existing theories. In the context of social CRM there are four theories that were used the most; The technology acceptance model (TAM), Diffusion of innovation (DOI), The technology- Organization- Environment framework (TOE), and the resource-based view (RBV) with its extension; the dynamic capabilities theory (Trainor et al., 2014).

These theories differ from each in their core determinants and importance; for example, TAM has been used as the starting point to understand the acceptance of social media technologies by organizational members and customers, and the impact this acceptance has on the adoption of Social CRM by enterprises, while TOE is described organizational- led theoretical perspectives (Ahani, Rahim, \& Nilashi, 2017; Yawised, 2017). A study on banks of Saudi Arabia by Askool \& Nakata, (2011) used TAM as a base construction of their conceptual proposal, further studies had to extend their model with other factors that impact social RM adoption such as, relative advantages, compatibility, complexity, top management support and organizational innovativeness.

According to Baker (2012), the TOE framework classifies the three main elements and their factors that impact an organization technologies adoption in terms of technology, organization and environment. Although this framework has a strong theoretical foundation and supported by many empirical studies in technology adoption (Oliveira \& Martins, 2011), it still has unclear major constructs (Wang et al., 2010) and it is too generic (Riyadh et al., 2009). Therefore, there is a need to support TOE framework, which could be accomplished by integrating it with other models that have clearer constructs.

Perceived usefulness (PU) and perceived ease of use (PEOU) are two constructs from technology acceptance model (TOE) that explain less than half of the system's use, and the extended variables of the model need more clarification. Therefore, it was suggested by researchers to integrate TAM with TOE framework in order to overcome some limitations. According to a study that conducted a model in cloud computing context by Gangwar \& Ramaswamy (2015), technological and organizational factors impact PU and PEOU which in their turn impact adoption intention, in addition to the environmental factors that have direct impact on adoption. Consequently, this study takes into consideration TOE framework as extended factors of TAM model.

\subsection{Proposed Framework and Hypotheses Development}

\subsubsection{Technological Context}

The technological factors of an organization may explain the attributes of a new innovative technology that would be adopted by an organization, these attributes are relative advantage, complexity, compatibility, tribality and observability (Thong, 1999). This paper considers relative advantage as an innovation technological element in the context of social CRM adoption. 


\section{Relative advantage:}

Relative advantage refers to the level to which an innovation or new technology is considered to provide more benefits for organizations (Rogers, 2003). In terms of CRM relative advantage describes the level to which the social CRM is considered to offer more advantages for an organization compared to the organizations following the traditional CRM (Marolt, 2018). As mentioned previously in the literature, social media has many advantages to offer for banks such as quick and immediate customer feedback on services, stronger relationship with customers and cutting costs. Therefore, the perceived advantages of social CRM can be expected to have an important role in the adoption of social CRM (Harrigan \& Miles, 2014; Sarner et al., 2010). Therefore, this study hypothesizes the following:

H1. Relative advantage has a positive impact on perceived usefulness.

H2. Relative advantage has a positive impact on perceived ease of use.

\subsubsection{Organizational Context}

Organization context refers to the attributes and resources of an organization which includes organization size, structures that link between employees, internal communication processes, and affordable resources (Baker, 2011). This paper will consider top management support as an element in the organizational context.

Top management support

Top management support is the level of support provided by the higher management in order to adopt innovation technology in business use, hence it plays an important role in the organizations' successful technology and innovation adoption (Grover \& Goslar, 1993).

Technological adoption is generally implemented using a top down approach; so the top management should value the importance of integrating technology in improving the organization performance and influence the organizational decision to adopt innovation technology (Law et al., 2013; Ramdani et al., 2009); Top management can then trigger the change by sharing its value with their employees (Thong, 1999), and keep them motivated by providing continuous support and showing commitment for creating a conductive implementation environment for technology and innovation adoption (Premkumar \& Roberts, 1998)

Hence, the level to which the top management support social CRM adoption compared with the traditional CRM or with contexts that lack CRM is an important factor in the successful implementation of social CRM (Ahani et al., 2017), so institutions that have support by top management for adopting new technologies are more likely to adopt social CRM (Abed, 2020). Therefore, the following hypotheses are formulated:

H3. Top management support has a positive impact on perceived usefulness.

H4. Top management support has a positive impact on perceived ease of use.

\subsubsection{Environmental Context}

The environmental context includes the presence or absence of technology service providers, the structure of the industry and the regulatory environment (Baker, 2011). CRM adoption studies used different attributes in the environmental context of TOE framework (Hasani et al., 2017). Consumer pressure and competitive pressure are two factors that encourage banks to adopt an innovation, and both will be considered in this paper.

Consumer pressure:

There are some relationship characteristics between organization and consumer such as encouragement, trust, commitment and pressure from customers which play a significant role in organizations' adoption of technologies (Abed, 2020; Gangwar \& Ramaswamy, 2015). Customer pressure describes customers' demand and behaviors that make enterprise adopt a new innovation (Peters et al., 2010). Based on the previous literature, the customer is no longer an object for sale, but defines the subject line instead which create the need for social CRM adoption. Institutions must implement a well-planned customer relationship management strategy in order to be responsive to customer pressure and to communicate effectively with their customers (Ahani et al, 2017; Premkumar \& Roberts, 1998). Meeting customers' expectations can motivate a positive adoption intention among banks. Thus, the following hypothesis is developed:

H5. Consumer pressure has a positive impact on social CRM adoption.

Competitive pressure:

Competitive pressure is defined as the level of fear the enterprise feel from losing competitive advantage when competing with other similar companies and its role is recognized as an effective motivator (Sin et al., 2016). 
Implementing information systems helps organizations to gain competitive advantage through adopting new methods in industry, structure, and competition (Porter and Millar, 1985). When the competition increases in the market, organizations start looking for innovative technologies to distinguish themselves and achieve sustainable competitive advantage. Social CRM helps attain this goal through brand awareness, more and better data collection, consequently better decision making (Cruz- Jesus et al., 2019). Competition is generally perceived to positively affect a new technology adoption specifically when it directly affects the competition and it is a strategic necessity to compete in the market (Ramadani et al., 2009). So, following hypothesis is proposed:

H6. Competitive pressure has a positive impact on social CRM adoption.

Perceived usefulness PU:

Tam proposes that PU is a significant factor affecting the acceptance of an information system (Davis et al., 1089). Davis defines PU as the level of belief a person have that using a specific system would improve his or her performance (Davis, 1989). Social CRM adoption is useful in determining and managing the social value of customers in banks, it also influences the perception of perceived usefulness and consequently influences the need for adoption (Askool and Nakata, 2012). So, following hypothesis is proposed:

H7. Perceived usefulness has a positive impact on social CRM adoption.

Perceived ease of use PEOUA:

Perceived ease of use as stated by TAM is a major factor which affects the acceptance of information system (Davis et al., 1989). PEOU is defined as the level of belief a person has that using a specific system would be effortless (Davis, 1989). The TAM model suggests that PEOU influences PU, because technologies that are easy to use can be more useful (Gangwar et al., 2015). So, following hypothesis is proposed:

H8. Perceived ease of use has a positive impact on social CRM adoption.

A conceptual framework of selected variables relevant to social CRM adoption is proposed based on prior literature.

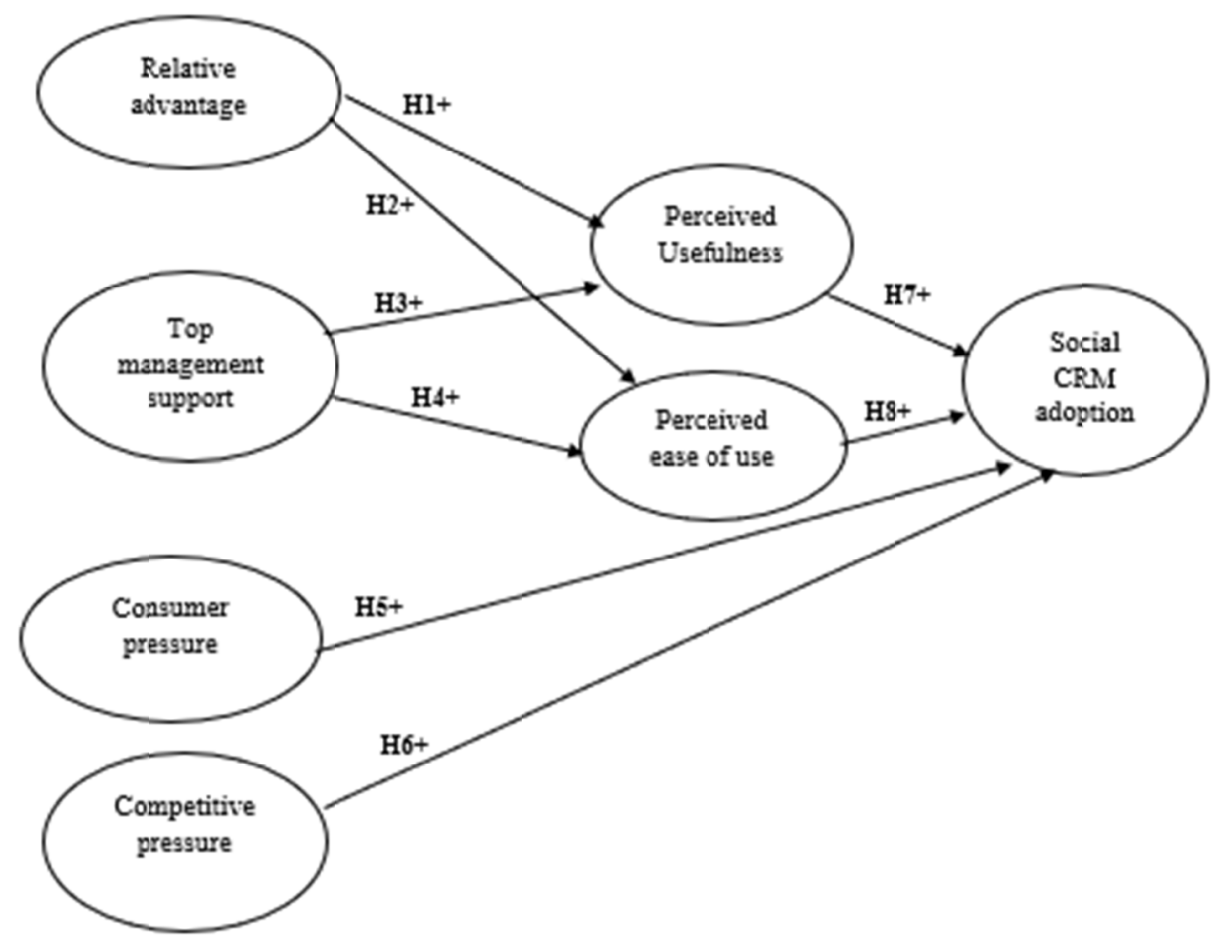

Figure 1. Conceptual framework 


\section{Methodology}

This research paper is a quantitative cross-sectional study that measures the selected constructs using scale items that depends on TAM model and TOE theoretical framework: Technology construct; Relative advantage (RAV), Organizational construct; top management support (TMS), Environmental constructs; consumer pressure (CSP), Competitive pressure (CPP), Perceived ease of use (PEOU), and Perceived usefulness (PU).

This study examined the factors that could influence banks employees' intention to participate in social CRM programs, therefore a quantitative survey was carried out to collect the data in order to examine the hypotheses since it seeks to apply the results in social CRM establishment and technology adoption in banks. Data collection method is from the information related to the theoretical subjects for research theoretical framework obtained from various books and publications, in addition to the information required for calculations of the research hypotheses collected through questionnaire submitted to banks' employees.

\subsection{Population and Sample}

The population consists of senior managers and employees of information technology, marketing and public relationship, and customer service departments of banks in Palestine. This study implemented random sampling. According to Bentler and Chou's (1987) who suggested for a minimum (subjects to item) ratio of 10:1, the 220 questionnaires that were collected from banks' employees were suitable for a SEM analysis technique of 22 items for further analysis.

\subsection{Data Collection}

Data was collected using an instrument that is well structured. Employees' questionnaire was developed through several phases. The first phase was generated from relevant studies reviewed, with adding the right instruction for a better understanding social CRM, the purpose of the study, and the researcher's information and contacts. To confirm content validity, informed individuals; information technology and marketing experts and faculty members served an expert review the first draft of the questionnaire.

The pilot test was conducted to discover any flaw or inconsistency in the questionnaire, and to solve any problem before the survey extended to the target participants after conducting pilot test, the modified questionnaire was emailed and administrated as a hard copy in person as well. All potential survey respondents were contacted through telephone, face to face or via e-mails, then after their confirmation to participate a modified online questionnaire through google web survey or hard copies of the questionnaire. A five- point scale ranging from "strongly agree" to "strongly disagree" was used to explore the degree of responses. Table 1 presents the scale items that are adopted to examine the constructs.

\subsection{Results}

Data analysis involved structural equations modeling techniques to the collected data. Statistical analyses were performed to examine the reliability, validity, path analysis and correlation of the scales were conducted in this research, to examine the relations among TAM and TOE variables and social CRM adoption. This study used Cronbach alpha to measure reliability and the internal consistency between measurement items of latent variables, and as mentioned before a pilot test also helped to establish the validity of the process. Table 2 presents the results of Cronbach's alpha test for each construct. Findings showed that reliability values for all the constructs are in high range and suitable for further analysis. Social CRM adoption construct has the highest value (0.878), and perceived ease of use has the lowest (0.748). 
Table 1. Scale items of selected constructs

\begin{tabular}{|c|c|c|}
\hline Construct name & Measurement item & Source \\
\hline \multirow[t]{3}{*}{ Relative advantage (RAV) } & $\begin{array}{l}\text { Implementing social CRM practices will } \\
\text { help us to gain competitive advantage. } \\
\text { (RAV1) }\end{array}$ & \multirow[t]{3}{*}{$\begin{array}{l}\text { Law et al., 2018; } \\
\text { Sophonthummapharn, 2009) }\end{array}$} \\
\hline & $\begin{array}{l}\text { Implementing social CRM would analyze } \\
\text { customer requirement in more efficient } \\
\text { way. (RAV2) }\end{array}$ & \\
\hline & $\begin{array}{l}\text { Implementing social CRM will help to } \\
\text { increase revenues. (RAV3) }\end{array}$ & \\
\hline \multirow[t]{3}{*}{ Top management support (TMS) } & $\begin{array}{l}\text { I think our top management will put clear } \\
\text { business objectives for employees in } \\
\text { implementing social CRM with respect to } \\
\text { customer satisfaction, retention and } \\
\text { expansion. (TMS1) }\end{array}$ & \multirow[t]{3}{*}{$\begin{array}{l}\text { (Premkumar \& Roberts, } \\
\text { 1999) }\end{array}$} \\
\hline & $\begin{array}{l}\text { Management would clearly indicate the } \\
\text { strategy of social CRM. (TMS2) }\end{array}$ & \\
\hline & $\begin{array}{l}\text { Our top management would encourage us } \\
\text { to follow social CRM objectives. (TMS3) }\end{array}$ & \\
\hline \multirow[t]{4}{*}{ Customer pressure (CSP) } & $\begin{array}{l}\text { I think that a lot of our customers are keen } \\
\text { that we have to implement social CRM } \\
\text { practices. (CSP1) }\end{array}$ & \multirow[t]{4}{*}{ (wu et al., 2003) } \\
\hline & $\begin{array}{l}\text { Our relationship with the main customers } \\
\text { could be suffered if we didn't implement } \\
\text { social CRM. (CSP2) }\end{array}$ & \\
\hline & $\begin{array}{l}\text { Customer will consider our organization as } \\
\text { backward if we didn't implement social } \\
\text { CRM. (CSP3) }\end{array}$ & \\
\hline & $\begin{array}{l}\text { A lot of customers demand to build a } \\
\text { stronger relationship with our organization } \\
\text { by social media. (CSP } 4)\end{array}$ & \\
\hline \multirow[t]{3}{*}{ Competitive pressure (CPP) } & $\begin{array}{l}\text { Our organization had a competitive } \\
\text { pressure to implement social CRM. (CPP1) }\end{array}$ & \multirow{3}{*}{ 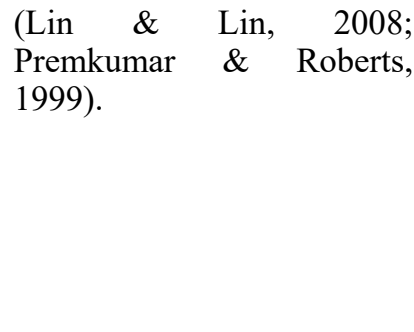 } \\
\hline & $\begin{array}{l}\text { Our organization may experience a } \\
\text { competitive disadvantage if we didn't } \\
\text { implement social CRM. (CPP2) }\end{array}$ & \\
\hline & $\begin{array}{l}\text { We think using social CRM is a strategic } \\
\text { importance to compete in marketplace. } \\
\text { (CPP3) }\end{array}$ & \\
\hline \multirow[t]{3}{*}{ Perceived ease of use (PEOU) } & $\begin{array}{l}\text { The process of using social CRM is easy to } \\
\text { understand. (PEOU1) }\end{array}$ & \multirow[t]{3}{*}{ (Gangwar et al., 2015) } \\
\hline & $\begin{array}{l}\text { Learning how to use social CRM practices } \\
\text { is easy for me. (PEOU2) }\end{array}$ & \\
\hline & $\begin{array}{l}\text { It's easy to make use of social CRM } \\
\text { practices is easy. (PEOU3) }\end{array}$ & \\
\hline \multirow[t]{3}{*}{ Perceived usefulness (PU) } & $\begin{array}{l}\text { Using social CRM allows me to manage } \\
\text { the operation of business efficiently. (PU1) }\end{array}$ & \multirow[t]{3}{*}{ (Gangwar et al., 2015) } \\
\hline & $\begin{array}{l}\text { Using social CRM leads to an increase in } \\
\text { productivity. (PU2) }\end{array}$ & \\
\hline & $\begin{array}{l}\text { Using social CRM allows to complete my } \\
\text { task more quickly. (PU3) }\end{array}$ & \\
\hline \multirow[t]{2}{*}{ Social CRM adoption (SCA) } & $\begin{array}{l}\text { In general, I think social CRM practices are } \\
\text { beneficial. (SCA1) }\end{array}$ & \multirow[t]{2}{*}{ (Gangwar et al., 2015) } \\
\hline & $\begin{array}{l}\text { In general, I am in favor of using social } \\
\text { CRM practices. (SCA2) }\end{array}$ & \\
\hline
\end{tabular}


Table 2. Reliability test for investigated constructs (Cronbach's alpha)

\begin{tabular}{lllll}
\hline Construct & Sample & No. of items & Cronbach's Alpha & $\begin{array}{l}\text { Reliability (as per } \\
\text { Hair et al., 2003) }\end{array}$ \\
\hline Relative advantage (RAV) & 220 & 3 & 0.806 & High \\
Top management support (TMS) & 220 & 3 & 0.772 & High \\
Consumer pressure (CSP) & 220 & 4 & 0.774 & High \\
Competitive pressure (CPP) & 220 & 3 & 0.804 & High \\
Perceived ease of use (PEOU) & 220 & 3 & 0.748 & High \\
Perceived usefulness (PU) & 220 & 4 & 0.811 & High \\
Social CRM adoption intention (SCA) & 220 & 2 & 0.878 & High \\
\hline
\end{tabular}

3.4 Hypotheses Testing

Hypotheses were tested by the analysis of path estimates via a critical t- value. All of the eight hypotheses testing were significant as shown in table 3.

The results of the squared multiple correlations (R2) is presented in table 4 . It shows the ability of one construct in predicting another (Hair et al., 2013). The model proposed in the study was able to explain $41 \%$ of the variance of social CRM adoption.

Table 3. Hypotheses testing results

\begin{tabular}{|c|c|c|c|c|c|c|}
\hline Independent variables & Dependent variables & Estimate & S.E. & C.R. & $\mathrm{P}$ & Significance \\
\hline Relative advantages & Perceived Usefulness & .387 & .054 & 7.192 & $* * *$ & Yes \\
\hline $\begin{array}{l}\text { Top management } \\
\text { support }\end{array}$ & Perceived ease of use & .246 & .058 & 4.241 & $* * *$ & Yes \\
\hline Relative advantages & Perceived ease of use & .346 & .059 & 5.838 & $* * *$ & Yes \\
\hline $\begin{array}{l}\text { Top management } \\
\text { support }\end{array}$ & Perceived usefulness & .243 & .053 & 4.610 & $* * *$ & Yes \\
\hline Consumer pressure & Social CRM adoption & .368 & .062 & 5.883 & $* * *$ & Yes \\
\hline Competitive pressure & Social CRM adoption & .135 & .055 & 2.435 & .015 & Yes \\
\hline Perceived usefulness & Social CRM adoption & .310 & .057 & 5.469 & $* * *$ & Yes \\
\hline Perceived ease of use & Social CRM adoption & .279 & .054 & 5.153 & $* * *$ & Yes \\
\hline
\end{tabular}

All significant where $\mathrm{p}<0.05$

Table 4. Squared Multiple Correlations

\begin{tabular}{ll}
\hline & Estimate \\
\hline PEOU & .268 \\
PU & .337 \\
SCA & .417 \\
\hline
\end{tabular}

\section{Discussion}

This study explored social CRM adoption by banks, by using the TAM model integrated with TOE framework. Path analysis was examined via structural equation modelling, and eight hypotheses were proposed. It was found that all of the hypotheses were significant.

Two hypotheses were tested in the technological context; the first is H1 which investigated the influence of relative advantage (RAV) on perceived usefulness (PU) to use social CRM. The relationship between RAV and PU was supported and it was found that this relationship is the most significant in this study as $(\beta=.387, p$ $<.001)$. H2 examined the impact of relative advantage (RAV) on perceived ease of use (PEOU), and it was also supported as $(\beta=.346 \mathrm{p}<0.001)$. These results are consistent with prior studies in technology adoption (Gangwar \& Ramaswamy, 2015; Chwelos et al., 2001; Musawa \& Wahab, 2012) that found that relative 
advantages were important elements of the usage of technology. The explanation of this result may refer that relative advantages of social CRM lead to better outcome such as_increasing efficiency in internal processes, make day to day duties much easier, improving productivity which lead to enhance customer service and increasing revenues.

In terms of organizational context, three items were occupied from Premkumar \& Roberts (1999) to measure top management support (TMS). Two hypotheses were tested; H3 explored the impact of top management support (TMS) on perceived usefulness (PU). The relationship between TMS and PU was supported $(\beta=.243, p>$ 0.001). H4 explored the effect of top management support (TMS) on perceived ease of use (PEOU). The relationship between TMS and PEAU was supported $(\beta=.246, \mathrm{p}<0.001)$. The results are similar to those of Gangwar \& Ramaswamy (2015), Ramadani et al. (2009) and Law et al. (2013). This indicates that business environment needs much support from managers in all the probable ways. Moreover, top management has a great impact in motivating their employees, as their continuous support for encouraging adoption environment in providing the needed resources and trained people for social CRM adoption.

The results of the study suggest that environmental determinants such as costumer pressure and competitive pressure have an important impact on social CRM adoption. H5 explored the impact of consumer pressure (CSP) on intention to adopt social CRM by banks (SCA). The relationship CSP and SCA was supported. Other studies found the positive and significant impact of consumer pressure on social CRM adoption intention such as; (Ahani et al., 2017; Hasani et al., 2017; Marolt, 2018). According to this study the impact of consumer pressure on social CRM adoption is the second significant relationship $(\beta=.368, p<.001)$. This significant relationship might refer that customers are depending on social media not only to communicate with others but also to foster a relationship with their preferable brands and associations that offer their needed services. This consumer behavior is challenging associations to apply social media capabilities, to develop additional relationship with their customers.

The other element in the environmental context is competitive pressure (CPP), as H6 examined the relationship between CPP and SCA and results provide indication that CMP has a significant impact on SCA as $(p<.05)$., this finding is consistent with prior studies (Hasani et al., 2017; Gangwar \& Ramaswamy, 2015; Sophonthummapharn, 2009). Significant relationship between competitive pressure and social CRM adoption indicates that when competitors adopt social CRM as a competitive tool in order to satisfy their customers and develop their competitive advantage, other organizations feel pressure of adopting social CRM as they face strong competition to maintain a competitive edge.

The results also showed that perceived usefulness (PU) in $\mathrm{H} 7$ and perceived ease of use (PEOU) in $\mathrm{H} 8$ have direct effect on social CRM adoption intention (SCA).

The relationship between PU and SCA was supported $(\beta=.310, p<0.001$, and the relationship between PEOU and SCA was also supported $(\beta=.279, \mathrm{p}<.001)$. PU and PEOU are considered from the main predictors of technology use intention (Davis, 1989). These findings are in line with earlier studies examining technology adoption for example (Abed, 2020; Askool and Nakata, 2011; Gangwar \& Ramaswamy, 2015).

\section{Theoretical and Practical Contribution}

This research paper provides a significant theoretical contribution for researchers, by exploring a new technology of social CRM that could be adopted by banks. The model of the research examined the factors that impact the social CRM adoption by banks. This was achieved by the integration between TOE and TAM to investigate the adoption of social CRM by banks. The research found a strong support for the dimensions proposed, as all of them are significant for banks adoption. Moreover, this study is the first to provide an empirical support for the adoption of social CRM by banks in Palestine.

In terms of implications for practice, based on our findings; banks need to recognize that social CRM is useful in accomplishing employees' duties in less time, by increasing their productivity which leads to an increase in outcome. In the organizational context, banks should be willing to implement the social CRM practices as a key strategy as this approach will help to gain competitive advantage. Moreover, banks have to respond to the pressure of their customers by adopting social CRM so banks won't be considered as backward.

\section{Limitations and Future Studies}

There are some limitations in this study; it explores the intention of the adoption not the actual use. Hence, future research could explore in the context of the actual usage of social CRM. Moreover, this study examines social CRM adoption intention from employee's perspective. Future research could observe social CRM adoption from consumers' perspective. The findings may not be generalizable as the population of the study is in Palestine, so 
future studies could explore other cultures or populations. The study used a sample of 220 employees, and it might create some difficulties in generalizing to a large population. Therefore, future research could explore larger sample size for a larger generalizing.

\section{Conclusion}

The study aims to explore the factors that impact social CRM adoption intention in banking sector. The TOE framework integrated with TAM model were the foundation of the proposed conceptual model. So as to accomplish the objective of the study, researcher conducted a quantitative survey that was distributed to collect the needed data. The findings from the survey of 220 employees in banks in Palestine indicated that eight hypotheses that were examined are significant. Findings also showed that relative advantages, top management support, consumer pressure, competitive pressure, PU, and PEOU are important factors for social CRM adoption in banks. Specifically, relative advantages in the technological context that has the most significant impact on perceived usefulness, and consumer pressure in the environmental context has the most significant direct impact on social CRM adoption in banks.

\section{References}

Abdelkareem, N. (2010). Adequate Financing of Palestinian MSMEs. The Palestine Economic Policy Research Institute (MAS), Ramallah, Palestine.

Abed, S. S. (2020). Social commerce adoption using TOE framework: An empirical investigation of Saudi Arabian SMEs. International Journal of Information Management, 53, 102118. https://doi.org/10.1016/j.ijinfomgt.2020.102118

Aggarwal, S., Mccabe, L., Leary, B., \& Aggarwal, A. (2012). Impact of Social Business in Small and Medium Business Study.

Ahani, A., Rahim, N. Z. A., \& Nilashi, M. (2017). Forecasting social CRM adoption in SMEs: A combined SEM-neural network method. Computers in Hum anBehavior, 75, 560-578. https://doi.org/10.1016/j.chb.2017.05.032

Ahmadalinejad, M., \& Nabavi, S. N. (2016). Social CRM: A solution for realization of virtual banking. International Journal of Mechatronics, Electrical and Computer Technology, 6(22), 3134-3141.

Alshawi, S., Missi, F., \& Irani, Z. (2011). Organizational, technical and data quality factors in CRM adoption SMEs perspective. Industrial Marketing Management, 40(3), 376-383. https://doi.org/10.1016/j.indmarman.2010.08.006

Askool, S., \& Nakata, K. (2011). A conceptual model for acceptance of social CRM systems based on a scoping study. Ai \& Society, 26(3), 205-220. https://doi.org/10.1007/s00146-010-0311-5

Baker, J. (2012). The technology-organization-environment framework. In Dwivedi Y., Wade M., \& Schneberger S. (Eds.), Information Systems Theory (pp. 231-245). Springer, New York, NY. https://doi.org/10.1007/978-1-4419-6108-2_12

Bentler, P. M., \& Chou, C. P. (1987). Practical issues in structural modeling. Sociological Methods \& Research, 16, 78-117. https://doi.org/10.1177/0049124187016001004

Bridge, L. (2017). Social CRM Applications and Impact in Small Businesses.

Cappuccio, S., Kulkarni, S., Sohail, M., Haider, M., \& Wang, X. (2012, August). Social CRM for SMEs: current tools and strategy. In Khachidze V., Wang T., Siddiqui S., Liu V., Cappuccio S., \& Lim A. (Eds.), Contemporary Research on E-business Technology and Strategy (pp. 422-435). Springer, Berlin, Heidelberg. https://doi.org/10.1007/978-3-642-34447-3_38

Charoensukmongkol, P., \& Sasatanun, P. (2017). Social media use for CRM and business performance satisfaction: The moderating roles of social skills and social media sales intensity. Asia Pacific Management Review, 22(1), 25-34. https://doi.org/10.1016/j.apmrv.2016.10.005

Chau, M., \& Xu, J. (2012). Business intelligence in blogs: understanding consumer interactions and communities. MIS Quarterly, 36, 1189-1216. https://doi.org/10.2307/41703504

Cheng, C. C. J., \& Shiu, E. C. (2019). How to enhance SMEs customer involvement using social media: The role of Social CRM. International Small Business Journal: Researching Entrepreneurship, 37(1), 22-42. https://doi.org/10.1177/0266242618774831 
Choudhury, M. M., \& Harrigan, P. (2014). CRM to social CRM: The integration of new technologies into customer relationship management. Journal of Strategic Marketing, 22(2), 149-176. https://doi.org/10.1080/0965254X.2013.876069

Cruz-Jesus, F., Pinheiro, A., \& Oliveira, T. (2019). Understanding CRM adoption stages: Empirical analysis building on the TOE framework. Computers in Industry, 109, 1-13. https://doi.org/10.1016/j.compind.2019.03.007

Davis, F. D. (1989). Perceived usefulness, perceived ease of use, and user acceptance of information technology. MIS quarterly, 13(2), 319-340. https://doi.org/10.2307/249008

Doern, R. (2009). Investigating barriers to SME growth and development in transition environments: a critique and suggestions for developing the methodology. International Small Business Journal, 27(3), 275-305. https://doi.org/10.1177/0266242609102275

Doole, I., Grimes, T., \& Demack, S. (2006). An exploration of the management practices and processes most closely associated with high levels of export capability in SMEs. Marketing Intelligence \& Planning, 24(6), 632-647. https://doi.org/10.1108/02634500610701690

Elfarmawi, W. (2019). Correlation between Customer Relationship Management System Usage, Product Innovation, and Customer Satisfaction. Foundations of Management, 11(1), 23-32. https://doi.org/10.2478/fman-2019-0002

Faase, R., Helms, R., \& Spruit, M. (2011). Web 2.0 in the CRM domain: defining social CRM. International Journal of Electronic Customer Relationship Management, $5(1), \quad 1$. https://doi.org/10.1504/IJECRM.2011.039797

Farnsworth, V. A. (2016). Social Customer Relationship Management in higher education.

Gangwar, H., Date, H., \& Ramaswamy, R. (2015). Understanding determinants of cloud computing adoption using an integrated TAM-TOE model. Journal of Enterprise Information Management, 28(1), 107-130. https://doi.org/10.1108/JEIM-08-2013-0065

Garrido-Moreno, A., Lockett, N., \& García-Morales, V. (2014). Paving the way for CRM success: The mediating role of knowledge management and organizational commitment. Information \& Management, 51(8), 1031-1042. https://doi.org/10.1016/j.im.2014.06.006

Greenberg, P. (2008). CRM at the speed of light: social CRM 2.0 Strategies, tools, and techniques for engaging your customers (4th ed.). McGraw Hill Professional.

Greenberg, P. (2010). The impact of CRM 2.0 on customer insight. Journal of Business Industrial Marketing, 25(6), 410-419. https://doi.org/10.1108/08858621011066008

Grover, V., \& Goslar, M. D. (1993). The initiation, adoption, and implementation of telecommunications technologies in US organizations. Journal of management information systems, 10(1), 141-164. https://doi.org/10.1080/07421222.1993.11517994

Guha, S., Harrigan, P., \& Soutar, G. (2018). Linking social media to customer relationship management (CRM): A qualitative study on SMEs. Journal of Small Business \& Entrepreneurship, 30(3), 193-214. https://doi.org/10.1080/08276331.2017.1399628

Hair, J. F. (2015). Essentials of business research methods. ME Sharpe.

Harrigan, P., \& Miles, M. (2014). From e-CRM to s-CRM. Critical factors underpinning the social CRM activities of SMEs. Small Enterprise Research, 21(1), 99-116. https://doi.org/10.1080/13215906.2014.11082079

Harrigan, P., Soutar, G., Choudhury, M., \& Lowe, M. (2014). Modelling CRM in a social media age. Australasian Marketing Journal, 23, 27-37. https://doi.org/10.1016/j.ausmj.2014.11.001

Hasani, T., Bojei, J., \& Dehghantanha, A. (2017). Investigating the antecedents to the adoption of SCRM technologies by start-up companies. Telematics and Informatics, 34(5), 655-675. https://doi.org/10.1016/j.tele.2016.12.004

Heller Baird, C., \& Parasnis, G. (2011). From social media to social customer relationship management. Strategy \& leadership, 39(5), 30-37. https://doi.org/10.1108/10878571111161507

Hoffman, D. L., \& Fodor, M. (2010). Can you measure the ROI of your social media marketing? MIT Sloan Management Review, 52(1), 41. 
Höhler, G. (2016). Social CRM in German retail banks (How social media is transforming the business world). Bearing Point $\mathrm{GmbH}$, Frankfurt.

Iacovou, C. L., Benbasat, I., \& Dexter, A. S. (1995). Electronic data interchange and small organizations: Adoption and impact of technology. MIS Quarterly, 19(4), 465-485. https://doi.org/10.2307/249629

Jacewicz, K., \& Cho, J. S. (2015). Analysis of archetypal characteristics of social customer relationship management. Journal of Business and Retail Management Research, 9(2), 85-99.

Jamieson, C. M. (2014). The Small Business' Guide to Social CRM. Packt Publishing Ltd.

Kantorová, K., \& Bachmann, P. (2018). Social customer relationship management and organizational characteristics. Information, 9(12), 306. https://doi.org/10.3390/info9120306

Katsioloudes, M., Grant, J., \& McKechnie, D. S. (2007). Social marketing: strengthening company-customer bonds. Journal of business strategy, 28(3), 56-64. https://doi.org/10.1108/02756660710746283

Küpper, T., Jung, R., Lehmkuhl, T., Walther, S., \& Wieneke, A. (2014, June). Performance Measures for Social CRM: A Literature Review. In Bled eConference (p. 31).

Küpper, T., Lehmkuhl, T., Wittkuhn, N., Wieneke, A., \& Jung, R. (2015, June). Social CRM Performance Model: An Empirical Evaluation. In Bled E Conference (p. 18).

Law, A. K., Ennew, C. T., \& Mitussis, D. (2013). Adoption of customer relationship management in the service sector and its impact on performance. Journal of Relationship Marketing, 12(4), 301-330. https://doi.org/10.1080/15332667.2013.846204

Lehmkuhl, T., \& Jung, R. (2013). Towards social CRM-scoping the concept and guiding research.

Lin, H. F., \& Lin, S. M. (2008). Determinants of e-business diffusion: A test of the technology diffusion perspective. Technovation, 28(3), 135-145. https://doi.org/10.1016/j.technovation.2007.10.003

Marolt, M., Pucihar, A., \& Zimmermann, H. D. (2015). Social CRM adoption and its impact on performance outcomes: A literature review. Organizacija, 48(4), 260-271. https://doi.org/10.1515/orga-2015-0022

Marolt, M., Zimmermann, H. D., Žnidaršič, A., \& Pucihar, A. (2020). Exploring Social Customer Relationship Management Adoption in Micro, Small and Medium-Sized Enterprises. Journal of theoretical and applied electronic commerce research, 15(2), 38-58. https://doi.org/10.4067/S0718-18762020000200104

Marolt, M., Zimmermann, H.-D., \& Pucihar, A. (2018). Exploratory Study of Social CRM use in SMEs. Engineering Economics, 29(4), 468-477. https://doi.org/10.5755/j01.ee.29.4.20246

McCann, M., \& Barlow, A. (2015). Use and measurement of social media for SMEs. Journal of Small Business and Enterprise Development, 22(2), 273-287. https://doi.org/10.1108/JSBED-08-2012-0096

Mostafapour, M., \& Heydariyeh, S. A. (2018). Providing a Model of Effective Factors to Successful Acceptance of Social CRM in Banks of Iran. Industrial Engineering \& Management Systems, 17(4), 757-768. https://doi.org/10.7232/iems.2018.17.4.757

Musawa, M. S., \& Wahab, E. (2012). The adoption of electronic data interchange (EDI) technology by Nigerian SMEs: A conceptual framework. Journal of Business Management and Economics, 3(2), 55-68.

Oliveira, T., \& Martins, M. F. (2011). Literature review of information technology adoption models at firm level. Electronic Journal of Information Systems Evaluation, 14(1), 110.

Palestinian Ministry of National Economy. Retrieved from https://www.met.gov.ps; http://www.psi.gov.ps

Peters, L. D., Pressey, A. D., \& Greenberg, P. (2010). The impact of CRM 2.0 on customer insight. Journal of Business \& Industrial Marketing, 25(6), 410-419. https://doi.org/10.1108/08858621011066008

PMA. (n. $\quad$ d.). The Palestine monitory authority. Retrieved from https://www.pma.ps/Default.aspx?tabid=383\&language=en-US

Premkumar, G., \& Roberts, M. (1999). Adoption of new information technologies in rural small businesses. Omega, 27(4), 467-484. https://doi.org/10.1016/S0305-0483(98)00071-1

Ramdani, B., Kawalek, P., \& Lorenzo, O. (2009). Predicting SMEs' adoption of enterprise systems. Journal of enterprise information management, 22(1/2), 10-24. https://doi.org/10.1108/17410390910922796

Rappaport, S. D. (2010). Cutting Edges: Listening-Led Marketing Science, Media Strategies, and Organizations. Journal of Advertising Research, 50(3), 305-315. https://doi.org/10.2501/S0021849910091464 
Riyadh, M., Akter, S., \& Islam, N. (2009). The adoption of e-banking in developing countries: A theoretical model for SMEs. International review of business research papers, 5(6), 212-230.

Rogers, E. M. (1995). The diffusion of innovations (4th ed.). New York: Free Press.

Sarner, A., Thompson, E., Dunne, M., \& Davies, J. (2010). Top use cases and benefits for successful social CRM. Gartner White Paper G, 209091.

Sigala, M. (2018). Implementing social customer relationship management: A process framework and implications in tourism and hospitality. International Journal of Contemporary Hospitality Management, 30(7), 2698-2726. https://doi.org/10.1108/IJCHM-10-2015-0536

Sin Tan, K., Choy Chong, S., Lin, B., \& Cyril Eze, U. (2009). Internet-based ICT adoption: Evidence from Malaysian SMEs. Industrial Management \& Data Systems, 109(2), $224 \mathrm{e} 244$. https://doi.org/10.1108/02635570910930118

Sophonthummapharn, K. (2009). The adoption of techno-relationship innovations: a framework for electronic customer relationship management. Marketing Intell. Plann., 27(3), 380-412. https://doi.org/10.1108/02634500910955254

Swift, R. S. (2001). Accelerating customer relationships: Using CRM and relationship technologies. Prentice Hall Professional.

Thong, J. Y. (1999). An integrated model of information systems adoption in small businesses. Journal of Management Information Systems, 15(4), 187-214. https://doi.org/10.1080/07421222.1999.11518227

Tornatzky, L. G., \& Fleischer, M. (1990). The Processes of Technological Innovation. Lexington books, Lexington, MA.

Trainor, K. J., Andzulis, J. M., Rapp, A., \& Agnihotri, R. (2014). Social media technology usage and customer relationship performance: A capabilities-based examination of social CRM. Journal of Business Research, 67(6), 1201-1208. https://doi.org/10.1016/j.jbusres.2013.05.002

Ujwala, K. (2015). Social CRM in banking-need of the hour. International Journal of Core Engineering \& Management, 2(2), 42-49.

Wang, Z., \& Kim, H. G. (2017). Can social media marketing improve customer relationship capabilities and firm performance? Dynamic capability perspective. Journal of Interactive Marketing, 39, 15-26. https://doi.org/10.1016/j.intmar.2017.02.004

Wongsansukcharoen, J., Trimetsoontorn, J., \& Fongsuwan, W. (2013). Social customer relationship management and differentiation strategy affecting banking performance effectiveness. Research Journal of Business Management, 7(1), 15-27. https://doi.org/10.3923/rjbm.2013.15.27

Wu, F., Mahajan, V., \& Balasubramanian, S. (2003). An analysis of e-business adoption and its impact on business performance. Journal of the Academy of Marketing Science, 31(4), 425-447. https://doi.org/10.1177/0092070303255379

Yawised, K., Ellis, L., \& Wong, M. C. (2017). The role and nature of SCRM in Australian private sector: an exploratory study. In Proceeding from the 2nd International conference on Advanced Research (Vol. 2, pp. 87-98). Asia Pacific Institute of Advanced Research.

Yoon, K., \& Sims, J. D. (2016). Integrating social media and traditional CRM: Toward a conceptual framework for social CRM practices. In Social Media and Networking: Concepts, Methodologies, Tools, and Applications (pp. 327-354). IGI Global. https://doi.org/10.4018/978-1-4666-8614-4.ch017

Zhu, K., Dong, S., Xu, S. X., \& Kraemer, K. L. (2006). Innovation diffusion in global contexts: Determinants of post-adoption digital transformation of European companies. European Journal of Information Systems, 15(6), 601-616. https://doi.org/10.1057/palgrave.ejis.3000650

\section{Copyrights}

Copyright for this article is retained by the author(s), with first publication rights granted to the journal.

This is an open-access article distributed under the terms and conditions of the Creative Commons Attribution license (http://creativecommons.org/licenses/by/4.0/). 